\title{
Inflexiones de lo (in)visible: la posdictadura chilena en los documentales de Marcela Said y Jean de Certeau
}

\author{
Inflections of the (in)visible: the Chilean post dictatorship \\ in the documentaries of Marcela Said and Jean de Certeau
}

\author{
https://doi.org/10.22235/d33.2375 \\ Mariano Veliz \\ ORCID: 0000-0002-3839-3622 \\ Universidad de Buenos Aires, Argentina.
}

\section{RESUMEN}

En este artículo se explora una serie de documentales dirigidos por Marcela Said y Jean de Certeau con el objetivo de rastrear los modos en los que allí se articulan estrategias para pensar el enlace de la transición democrática chilena y el problema de la visibilidad. Los análisis de I Love Pinochet (Said, 2001), Opus Dei: una cruzada silenciosa (Said y De Certeau, 2006) y El mocito (Said y De Certeau, 2011) privilegian el conflicto derivado del acceso o no a la visibilidad. En esa búsqueda, el artículo pone en diálogo los tres documentales con diversas teorías que piensan los dilemas de lo visible en la contemporaneidad. Estos intercambios entre la teoría y la producción documental permiten concluir que en estos documentales se desmonta el funcionamiento de la visibilidad y la discursividad puestas en juego en el período posdictatorial en Chile.

Palabras clave: Chile, posdictadura, visibilidad, cine, documental.

\begin{abstract}
The article explores a series of documentaries directed by Marcela Said and Jean de Certeau with the aim of thinking the strategies articulated there to reflect on the link between Chilean democratic transition and the problem of visibility. The analysis of I Love Pinochet (Said, 2001), Opus Dei: una cruzada silenciosa (Said and De Certeau, 2006) and El mocito (Said and De Certeau, 2011) emphazise on the conflict derived from the access or not to visibility. In this search, the article puts in dialogue the three documentary films with different theories that address the dilemmas of the visible in contemporary world. These exchanges between theory and documentary productions allow us to conclude that in these films is dismantled the operation of visibility and discursiveness configured in the post-dictatorial period in Chile.
\end{abstract}

Keywords: Chile, post dictatorship, visibility, cinema, documentary.

Cómo citar: Veliz, M. (2020). Inflexiones de lo (in)visible: la posdictadura chilena en los documentales de Marcela Said y Jean de Certeau. Dixit, 33, 26-40. https://doi.org/10.22235/d33.2375

Recepción: 15/06/2020 :: Revisión: 04/09/2020 :: Aceptación: 10/09/2020 


\section{Documentales y transición democrática}

Marcela Said dedicó tres documentales (I Love Pinochet, 2001; Opus Dei, una cruzada silenciosa, 2006, codirigido con Jean de Certeau; El mocito, 2011, codirigido con Jean de Certeau) ${ }^{1}$ y dos largometrajes de ficción (El verano de los peces voladores, 2013; Los perros, 2017) a interrogar, con distintas intensidades, las continuidades entre el período dictatorial y la incipiente democracia chilena, así como a indagar las formas en las que la visibilidad y la audibilidad se inscriben como problemas específicos del período transicional. ${ }^{2}$ Si bien ambas problemáticas son recurrentes en el cine chileno, el abordaje propuesto por Said en sus documentales implica la aparición de una torsión significativa.

Diferentes estudios sobre el cine chileno reciente dan cuenta de esta posición heterodoxa. En El documental chileno, Jacqueline Mouesca (2005) menciona sucintamente I Love Pinochet en un apartado en el que investiga los documentales políticos realizados por cineastas mujeres en las proximidades del año 2000. En ese contexto, la historiadora explora la emergencia de La flaca Alejandra (Carmen Castillo, codirigido con Guy Girard, 1994); El derecho de vivir en paz (Carmen Luz Parot, 1999), en el que se recompone la trayectoria vital y el asesinato de Víctor Jara; Estadio Nacional (Carmen Luz Parot, 2001), articulado a través del entramado de decenas de voces testimoniales y La venda (Gloria Camiruaga, 2001), en el que se recuperan las voces de mujeres que padecieron la violencia dictatorial. Mouesca incluye I Love Pinochet en este corpus privilegiando tanto una referencia biográfica (Said es una cineasta) como una dimensión temática (las supervivencias del pinochetismo en la sociedad civil).

Más allá de este esbozo de clasificación, los primeros documentales dirigidos por Said pueden parecer excéntricos en el marco del documentalismo chileno contemporáneo. Si entre las tendencias dominantes se destaca el protagonismo de las narrativas autobiográf1- cas, estas producciones quedan ineludiblemente ajenas a esta orientación. Valeria de los Ríos y Catalina Donoso (2016) rastrean la eclosión de la impronta autobiográf1ca a partir de los comienzos del siglo XXI. Si Mouesca había propuesto que los documentales de Said y Castillo participaran de un mismo corpus, en este caso esa aseveración puede interrogarse.

En La flaca Alejandra, Carmen Castillo aborda, desde la inscripción de su voz y su cuerpo, la potencia de la primera persona. La voluntad de esclarecer el accionar de Marcia Merino, una dirigente del Movimiento de Izquierda Revolucionaria (MIR) devenida -luego de ser secuestrada y torturada por la DINA ${ }^{3}$ - en una de sus principales informantes durante la dictadura, es atravesada por la permanente reaparición de la propia experiencia de la cineasta: el asesinato de su pareja (el dirigente del MIR Miguel Enríquez), el exilio, el retorno al Chile de la transición, el encuentro con antiguas compañeras de militancia.

Por el contrario, en I Love Pinochet la entrada de la subjetividad está siempre limitada, cercada por la intención de construir un documental con una mayor apariencia de objetividad. Por este motivo, en la exploración llevada a cabo por De los Ríos y Donoso (2016), Estadio Nacional y I Love Pinochet aparecen como referentes de una corriente de documentales de temática

$1::$ Previamente había dirigido Valparaíso dentro de la serie documental L'écume des villes (1998) para la productora televisiva Paris Première.

2:: Miguel Valderrama (2018) reflexiona acerca de la dificultad para nombrar el tiempo que sigue a la dictadura. En su argumentación, "la posdictadura nombra acaso ese trabajo de registro a la vez interno y externo a partir del cual la dictadura se escribe, se inscribe sobre sí misma, en una perpetua reescritura del presente" (p. 20). La apelación a la noción de "transición" en este artículo no propone la asunción de un tiempo de reconciliación. Por el contrario, se aboga por una comprensión de su carácter conflictivo e irresuelto.

3:: Dirección de Inteligencia Nacional, policía secreta de la dictadura de Augusto Pinochet. 
política ajena a los abordajes que privilegian la mirada personal en el marco del giro autobiográfico. ${ }^{4}$

Este lugar también se evidencia en su no pertenencia a las "formas expandidas" estudiadas por Iván Pinto (2016). A Pinto le interesa explorar una serie de documentales chilenos recientes que se asientan en el territorio de lo experimental. Estas formas expandidas introducen, además de la preeminencia de la subjetividad, la indeterminación entre ficción y documental, la oscilación entre control y descontrol de la puesta en escena, la proliferación de recursos expresivos, el remontaje experimental del archivo, la exploración perceptual y afectiva. Frente a la proliferación de estos recursos, los documentales dirigidos por Said y De Certeau se posicionan como artefactos que pueden parecer remanentes de otras épocas. En esta dirección, Vania Barraza (2018, p.67) postula su carácter descentrado, en un contexto en el que, si bien el cine documental abordó la historia chilena reciente, lo hizo privilegiando la experiencia personal y la perspectiva de los cineastas en su infancia (inscribiendo así su memoria y su subjetividad). ${ }^{5}$

Este carácter anacrónico convierte a los documentales de Said y De Certeau en dispositivos incómodos, perturbadores tanto de las cronologías del cine chileno -en las que no se privilegia su gesto denuncialista- como de la concepción de sus documentales como meras actualizaciones del cine militante previo al Golpe de Estado de 1973. Su cine puede coincidir con este en su voluntad de intervención y en su intención pedagógica, pero no participa de su confianza en la eficacia mensurable del arte ni de un proyecto estético-político en el que las producciones simbólico-culturales se piensen en función de su puesta al servicio de programas ideológicos descolonizadores y revolucionarios.

En estos documentales, el pasado totalitario se inscribe como problema del presente. Se trata de dos temporalidades imbricadas y no separadas por un límite preciso. El pasado asedia al presente a través de sus espectros y sus huellas. Nelly Richard (2015) sugiere al respecto que para que el recuerdo del pasado de la dictadura y sus víctimas adquiera fuerza de interpelación "necesitamos contar con una narración del pasado que deje entreabiertas las mallas de significación de una memoria que debe permanecer inconclusa para que dicha memoria renueve sus fuerzas de invocación que llamarán a nuevos ensamblajes críticos” (p. 141). Ante las demandas de memorias plenas, Richard defiende la emergencia de memorias inconclusas $\mathrm{y}$ fragmentadas.

Said y De Certeau comparten ese interés, aunque con la particularidad de no recomponer las memorias y los relatos de las víctimas de la dictadura, sino de algunos de sus perpetradores y defensores. Si Richard se pregunta cómo es posible conjugar esa memoria del ayer en el tiempo presente, para alcanzar una reactivación transformadora del recuerdo que lo habilite para nuevas aventuras, Said y De Certeau se preguntan cuáles son las estrategias que permiten preservar no solo las memorias en peligro, sino cómo sortear los peligros de algunas memorias. En este caso, el riesgo reside en la oscuridad en la que queda agazapada esta otra memoria de la dictadura, activa en el presente y amenazante sobre la democracia recién recuperada. De ahí deriva la voluntad de interrogar esas memorias, escuchar esos relatos y visibilizar esas construcciones de sentido.

4:: Una de las corrientes más relevantes para evaluar la emergencia de este cine reside en los documentales dirigidos por hijos de detenidosdesaparecidos, exiliados o perseguidos políticos. En este vasto corpus pueden destacarse: En algún lugar del cielo (Alejandra Carmona Cannobbio, 2003), El telón de azúcar (Camila Guzmán Urzúa, 2005), El edificio de los chilenos (Macarena Aguiló, 2009), El eco de las canciones (Antonia Rossi, 2010), Venían a buscarme (Álvaro de la Barra, 2016). Véase: Vergara y Bossy (2010), Donoso Pinto (2012), Marin (2019).

5:: Resulta interesante pensar cómo confluye esta no pertenencia a las tendencias más estudiadas del documentalismo chileno con el reconocimiento que recibieron sus documentales. Esto puede evidenciarse en los premios obtenidos: I Love Pinochet fue premiado en el Festival Internacional de Cine de Valparaiso y en el Festival Internacional de Documentales de Santiago; Opus Dei... recibió el premio Pedro Sienna; El mocito obtuvo premios en el Festival de Cine Documental de Múnich, en el Festival Internacional de Documentales de Santiago y en el Festival de Valdivia. 
El abordaje de los problemas transicionales no puede desprenderse de la necesidad de pensar las formas en las que se narran los tiempos de catástrofe. Para Richard (2010), qué relatos se urden de los tiempos de la dictadura y con qué lenguajes se transmite la experiencia traumática son dos preguntas ineludibles del período posdictatorial, para "no fallarle éticamente a la desgarrada memoria de las víctimas, sin renunciar, al mismo tiempo, a la necesidad de trasladar esta experiencia del pasado-pasado hacia los ejes móviles de posicionalidad crítica de un presente-futuro" (p. 21).

Acuciada por estos interrogantes, Richard explora el período 1990-2010 -los años de instauración del consenso como molde de la reconciliación nacional retorizada-, desde el ascenso al poder de Patricio Aylwin en 1990, con el presunto ánimo de superar los antagonismos del pasado violento, hasta concluir en 2010, con la inauguración del Museo de la Memoria y los Derechos Humanos que escenifica la culminación institucional de la narrativa de la memoria oficializada por la transición chilena (Richard, 2010, p. 9). ${ }^{6}$ En ese contexto, articula una crítica de los dispositivos de la memoria oficial que buscaron apaciguar el recuerdo y decretar la "compulsión al olvido" y "el bloqueo de la memoria" (Moulian, 1997). Frente a estas persistencias, se trata de desarmar la memoria oficial de la transición chilena que buscó apaciguar el recuerdo y desmentir las batallas de interpretación sobre el pasado en discordia. En ese marco político y discursivo, pero también organizador de la producción y la circulación de las imágenes, los documentales dirigidos por Said y De Certeau se pliegan a las guerras de asignación de sentido sobre el pasado reciente.

I Love Pinochet, Opus Dei y El mocito se dedican, en diversos grados y con distintas modulaciones, a la interpelación exhaustiva no solo de la connivencia de la sociedad civil con el exterminio, sino a su necesidad para la implementación del "Big Bang de la globalización”, como llama Willy Thayer al Golpe de Estado de 1973, concebido como plataforma de la implementación global de las políticas neoliberales (Thayer, 2006). Con- viene, en este punto, recuperar la proposición de Sergio Villalobos-Ruminott (2016) acerca de la necesidad de inscribir la historia de la violencia desaparecedora en el proyecto de acumulación capitalista. Ese gesto lo opone a las retóricas oficiales y a los rituales conmemorativos que decidieron expulsar las referencias a la inserción del terrorismo de Estado en el marco del establecimiento del laboratorio neoliberal.

La historia del capital, así percibida, no es solo la del progreso y la modernización, del desarrollismo y la industrialización, sino también la del cadáver y la muerte (Villalobos-Ruminott, 2016, p. 202). Ante esta imbricación, Villalobos-Ruminott se aleja de la tendencia a espectacularizar la muerte en lo que llama, en una torsión del pensamiento benjaminiano, la "época de la reproductibilidad técnica del cadáver” (p. 209) y sugiere que la tarea a cumplir no consiste en ordenar los huesos y los cadáveres como si se organizara un archivo, "sino en desenterrar los secretos de la acumulación y hacer posible la pregunta por la justicia” (p. 213).

Marcela Said y Jean de Certeau recuperan estos desafíos y articulan, a partir de allí, una estrategia en torno a lo visible: posicionar en el centro de la imagen y la escucha no los testimonios de las víctimas, sino los sistemas de alianzas que posibilitaron la implementación de las políticas criminales de la dictadura. Así, buscan fragilizar ciertas territorialidades del poder a través de la implementación de formas de hacerlo visible y audible, en un desmontaje de las maneras en las que este decide presentarse a sí mismo. Esta posición resulta heterodoxa en relación con la tendencia prioritaria en el cine chileno del período transicional, dedicada a hacer audibles y visibles los testimonios de los exiliados, los antiguos presos políticos y los familiares de los desaparecidos.

De esta manera, el documentalismo se apropiaba del espacio dejado vacío por la Justicia y que no había logrado

6:: Tampoco puede desestimarse la relevancia del ascenso al poder de Sebastián Piñera en 2010 y la repercusión de este giro político en las narrativas y las memorias sobre la dictadura. 
cubrir el Informe Rettig". Este informe, "al sacar a la tortura de sus recuentos de la violencia destructiva para limitarse a los casos de ejecutados y desaparecidos políticos, restringió la condición de víctima excluyendo de ella a las identidades destrozadas de los sobrevivientes" (Richard, 2010, p. 37). Ante la subordinación ejercida por el Informe Rettig de la fuerza subjetiva de la testimonialidad de los sobrevivientes, los audiovisuales documentales cumplieron la misión de restituirles una dimensión de saber por la experiencia. Ante la emergencia de estas producciones testimoniales, Said y De Certeau esgrimen la mencionada estrategia de no mostrar a las víctimas del poder totalitario, sino a sus responsables, colaboradores, defensores y ejecutores.

Si el poder emplea la visibilidad como recurso de control, una resistencia posible supone desarticular esa manera de ejercer la visibilidad y someter a escrutinio a los propios detentadores de la mirada-poder. En su vasto estudio de las concepciones de la visión en el pensamiento francés del siglo XX, Martin Jay (2007) discute la concepción de la vista como un sentido puesto al servicio de la objetivación del otro y expone que esta noción se piensa siempre desde la potencia del poder de cooptarla como pertenencia propia (pp. 397-398). Frente a la recurrencia de este abordaje, Jay propone explorar la capacidad de la visión como mecanismo de resistencia (p. 314). En esta senda, la apuesta de los documentales de Marcela Said y Jean de Certeau resulta contundente: la reticulación, la observación y la escucha como ejercicios de desmantelamiento de las operatorias del poder.

\section{Love Pinochet: la visión del cine-funa}

En el marco histórico y discursivo de la Concertación (19902010), la detención de Augusto Pinochet en Londres en 1998 supuso la apertura de memorias que habían quedado soterradas entre las memorias oficiales de la posdictadura. Nelly Richard (2010) precisa que este episodio "hizo estallar la zona de acumulación de lo no dicho en cuyo silencio se habían depositado, durante los primeros años de la transi- ción, las frustraciones de los familiares de las víctimas que reclamaban por la lentitud de la justicia” (pp. 32-33). Sin embargo, no fueron solo esas memorias desterradas las que adquirieron una nueva y potente presencia en el espacio público. La captura de Pinochet también recrudeció la circulación de las memorias de quienes compartían su proyecto ideológico y reclamaban la necesidad de ocupar el mismo espacio público. ${ }^{8}$ En esa distribución de las voluntades políticas, su detención propició la organización de diversas acciones tendientes a lograr su liberación. Si bien estas operaciones eran en parte públicas, y por lo tanto visibles, se trataba de iniciativas que regulaban su propio aparecer. Ante esta evidencia de la capacidad del poder, Marcela Said decide explorar en I Love Pinochet nuevas formas de visibilizar a los soportes civiles y militares de la dictadura durante los primeros años de la restauración democrática. ${ }^{9}$

Los sectores de poder supieron siempre aquello que Édouard Glissant (2006) recomendaba como estrategia de resistencia a las identidades antillanas sojuzgadas por el colonialismo europeo: la defensa de la opacidad, la certeza de que en los regímenes escópicos dominados por la hipervisibilidad, la sustracción a lo visible puede funcionar como modalidad de resistencia. I Love Pinochet configura un muestrario de las formas en las que el

7:: Informe presentado como resultado de la investigación llevada adelante por la Comisión Nacional de Verdad y Reconciliación, presidida por Raúl Rettig. Este organismo fue creado por el presidente Patricio Aylwin en 1990 para esclarecer las violaciones a los derechos humanos durante la dictadura.

8:: El aval social con el que contaban estos posicionamientos se evidencia en el resultado del plebiscito nacional de Chile en 1988: el $44 \%$ de los electores votó la continuidad de Pinochet en el poder. El dictador siguió en funciones como comandante en jefe del Ejército hasta 1998 y ejerció durante algunos meses a partir de ese momento como senador vitalicio.

9:: Resulta ineludible la referencia a El caso Pinochet (2001), documental en el que Patricio Guzmán sigue el proceso judicial e incluye las voces de sus víctimas. 
discurso pinochetista regula sus maneras de aparecer en ciertos espacios públicos o semipúblicos -las conferencias brindadas en el Instituto General Augusto Pinochet, las clases impartidas en la Escuela premilitar, las fiestas organizadas en las sedes de la Unión Demócrata Independiente (UDI), las convenciones de empresarios- y en espacios privados, en especial en los modos de vida defendidos por la burguesía beneficiada por la dictadura y que fue, al mismo tiempo, una de sus artífices. ${ }^{10}$

Si la visión constituye siempre un campo conflictivo, esto deriva en gran medida de la posible reversión del observador en cuerpo ofrecido a la mirada. A pesar de los permanentes intentos por delimitar esos roles de manera inalterada, la resistencia no deja de combatir para asegurar la puesta en visibilidad de los espacios de poder. En esta dirección, el gesto emprendido por Said no se orienta a hacer visible lo invisible, sino a hacerlo visible de un modo que desorganice el funcionamiento de sus propias formas de aparecer. ${ }^{11}$ El documental se construye como acción de registro de una visibilidad que debe ser interrogada y sometida a evaluación. La urgencia de su intervención resulta manifiesta: el recrudecimiento de las memorias pinochetistas no busca solo restaurar la imagen pública del antiguo dictador, sino incidir en el futuro político del país.

La intervención sobre el funcionamiento de la visión propiciada por el documental de Said conduce a la posibilidad de percibir allí su gesto de mayor radicalidad. Su documental puede pensarse a partir de la noción de "funa": término que define, en mapudungún, mapuche o araucano, la acción de pudrirse, y que derivó en la forma de referirse a las manifestaciones de repudio y denuncia en contra de quienes cometieron violaciones a los derechos humanos. Tras la detención de Pinochet, manifestantes por los derechos humanos se reunieron en vigilias organizadas por la Agrupación de Familiares de Detenidos Desaparecidos. A partir de estos encuentros se fundó la organización Acción, Verdad y Justicia (HIJOS Chile). El acceso a información sobre los ejecutores y participantes de la violencia de la dictadura propició la organización de funas, en las que se denunciaba públicamente la responsabilidad en los crímenes cometidos durante la dictadura. Ante la impunidad sistemática, se extendió el lema de la Comisión Funa: "Si no hay justicia, hay funa”. El documental de Said explora la posibilidad de trasladar esta lógica al universo audiovisual. Pero lo hace a través de un desplazamiento: la funa se articula mediante la gestación de la visibilidad y la audibilidad de los soportes civiles de la dictadura.

La aparición de I Love Pinochet no puede desprenderse de la urgencia por filmar las defensas del pinochetismo antes de que este gesto fuera sometido por la hegemonía de lo políticamente correcto y su consiguiente traslado al espacio (semi)privado. La circulación de estas discursividades en el período posdictatorial, incrementada ante la detención de Pinochet, no solo funciona como acto ostentatorio de su poder remanente, sino también como gesto político que busca condicionar el proceso transicional. La permanencia de estos discursos y de las acciones que son su base favorece un análisis de las continuidades entre el régimen dictatorial y la restauración democrática más que de sus rupturas. En esta dirección, Said no comienza su documental con la detención -acontecimiento histórico que habilita, como precisa Richard, la irrupción de esas otras imágenes y relatos que habían quedado marginados

10:: En concordancia con esta preocupación, en distintas entrevistas sobre Los perros (2017) Marcela Said remite al libro El saqueo de los grupos económicos al estado chileno, de María Olivia Mönckeberg (2001).

11:: Mouesca piensa como antecedente la tetralogía Chili-impressions, de José María Berzosa, quien viajó a Chile en 1977 para entrevistar a los integrantes de la Junta Militar y revelar sus sistemas de alianzas con la sociedad civil. En sus documentales, acuciados por la necesidad de incidir en la opinión pública europea, se introduce, junto con la discursividad de los militares, los testimonios de los familiares de los desaparecidos en un lugar dominante. En el caso del documental de Said, la priorización de las voces de los pinochetistas supone el saber histórico acerca de sus violaciones a los derechos humanos. 
en el espacio público chileno-, sino con su liberación y los festejos de sus adeptos. ${ }^{12}$ Así, subraya no solo este campo de persistencias, sino también la vitalidad de esos discursos y esas políticas en el marco de la recuperación democrática (Figura 1).

Si la captura y posterior liberación ponen en escena el poder pinochetista, Said lo asienta en la potencia del "yo" que enuncia I Love Pinochet. Ese yo enunciado en inglés remite a los lazos del régimen militar con el idioma del capitalismo y afirma su formulación en el campo de los lemas gestados por el marketing y su consecuente conversión de la ideología en mercancía. A su vez, se trata de un "yo" engañoso dado que es un yo colectivo. El "nosotros" que esconde aparece reiteradamente en los discursos de los entrevistados, asentando la noción de una identidad fuertemente cohesionada. El documental despoja a los testigos del anonimato que los protege detrás del impreciso "nosotros" al que apelan con regularidad. ${ }^{13}$ La identificación del nombre y el registro de sus discursos suponen exponer su posicionamiento y abrirlo a la lectura crítica.

A pesar de la preeminencia asignada a los rostros y los discursos de los pinochetistas, en el documental se apuesta a una polifonía controlada. En especial, a través de la introducción de una discusión entre dos estudiantes que sostienen posturas opuestas sobre la historia chilena (una joven que defiende lo actuado por la dictadura y un joven que evidencia el carácter clasista de esa defensa y señala, a través de una inflexión autobiográfica, que su padre fue torturado durante la dictadura) y mediante la incorporación de una entrevista al historiador Alfredo Jocelyn Holt, quien explicita la necesidad del Golpe de Estado de 1973 en función del establecimiento del modelo neoliberal. Ambas inclusiones manifiestan la voluntad de sumar la voz de actores sociales que por cercanía o por erudición desbaraten las argumentaciones de los pinochetistas. Así, hacen evidente la exigencia de impugnar la circulación de estos discursos en un contexto en el que no estaban todavía sofocados. Nelly Richard (2010) puntualiza al respecto que el pasado malherido reacontece cada vez "que vuelve a ser ofendido por el cinismo de la mentira o las imposturas de la

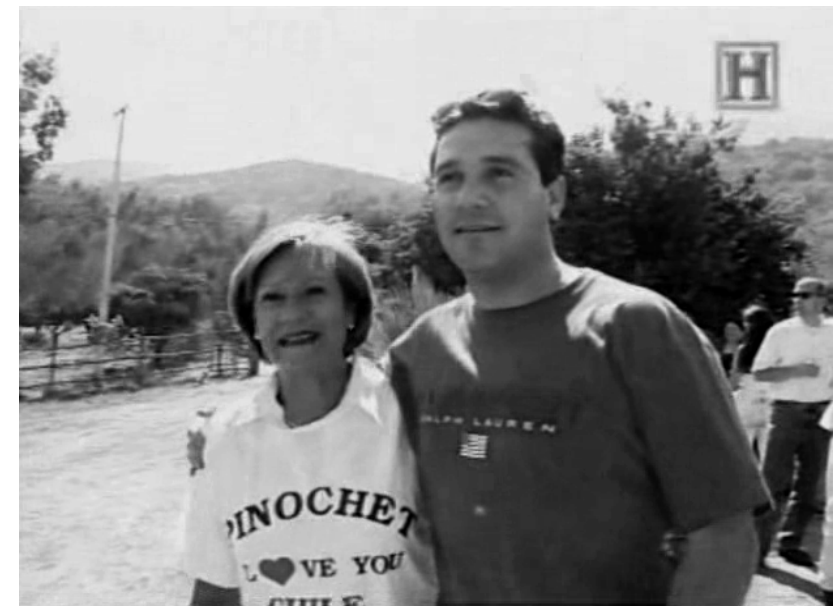

Figura 1: Fotograma de / love Pinochet

razón con las que la derecha chilena niega o relativiza los abusos criminales del régimen militar" (p. 27). La escucha atenta de estas memorias permite encontrar las previsibles contradicciones y desarmar la presunta homogeneidad de las argumentaciones. El peligro de estos discursos irrumpe en una escena filmada en la Escuela premilitar. En una clase dedicada a combinar las enseñanzas religiosas y la exaltación del régimen militar, Bernardo Acuña afırma: "Cuando nos pidan que estemos, vamos a estar". Esta frase, lanzada como proclama, funciona como amenaza vertida sobre el presente y el futuro.

El desafío del documental reside en la construcción de un punto de vista: ¿cómo narrar a los pinochetistas sin identificarse con su perspectiva? Este interrogante explica la aparición esporádica de una voice over femenina, adjudicada a la realizadora, que aporta informaciones y

12:: Richard (2010) señala que la muerte de Pinochet no despertó tantas reacciones como su detención y enterró una parte de las energías que lo defendían. En La muerte de Pinochet (Bettina Perut e Iván Osnovikoff, 2011) se aborda este episodio a través de los rituales mortuorios, los lemas y las expresiones de dolor de sus defensores. El tono exaltado de los lamentos se contrapone a los festejos simultáneos de quienes celebran la muerte. Perut y Osnovikoff articulan una necroestética profana, en la que el cadáver y la liturgia se conciben como cuerpos políticos.

13:: Se trata de una identidad colectiva de la que forman parte el sacerdote Raúl Hasbún, el economista y político Joaquín Lavín, el filósofo Fernando Moreno Valencia, el abogado Fernando Barros Tocornal, el dirigente de la UDI Enrique Jara, el político y exagente de la DINA Cristián Labbé, los editorialistas del periódico El Mercurio y los integrantes de la familia Arcos, muy alejados de los espacios de poder. 
eventuales giros personales ("en mi país un porcentaje elevado de ciudadanos apoyan al exgeneral, aun en conocimiento de los abusos y violaciones a los derechos humanos. ¿Quiénes son los pinochetistas y qué piensan algunos de ellos, que siguen controlando aspectos importantes de la opinión pública nacional?”). Esta voz constituye el principal recurso empleado por Said para anclar el sentido de las imágenes y las entrevistas. Su carácter explícito parece depender de la voluntad de evadir el mencionado peligro de la ambigüedad y la posible sumisión del documental a la discursividad pinochetista en el escenario político-ideológico de la transición.

Frente al uso subrayado de esta voz, sobresale la inclusión de imágenes que capturan el espacio público en los traslados de la cineasta para realizar las entrevistas. Así, se registran planos diurnos y nocturnos de las calles y las rutas, los desplazamientos de los transeúntes, los contrastes entre la densidad poblacional de la ciudad y los espacios en blanco de las zonas rurales, la diferencia entre las áreas privilegiadas y las abandonadas, la emergencia de los lugares de consumo en sus diferentes variantes, y se compone una cartografía, imprecisa e incompleta, de la sociedad chilena de la posdictadura. Esas travesías de la imagen entran en tensión con el carácter explícito de la mencionada voz. Ese vínculo conflictivo permite inscribir la experiencia totalitaria en los cuerpos y en los espacios. A su vez, en las trayectorias espaciales se visibilizan los efectos de la imposición del modelo neoliberal durante el régimen pinochetista (Figura 2).

\section{Opus Dei, una cruzada silenciosa: ejercicios de (in)visibilidad}

En Nocturno de Chile (2011), Roberto Bolaño narra la historia reciente de Chile desde una perspectiva perturbadora: el personaje-narrador, Sebastián Urrutia Lacroix, es un sacerdote y crítico literario (bajo el seudónimo $\mathrm{H}$. Ibacache) cuyo compromiso con la dictadura lo conduce a convertirse en formador intelectual de los cuadros de la Junta de gobierno después del Golpe de Estado.

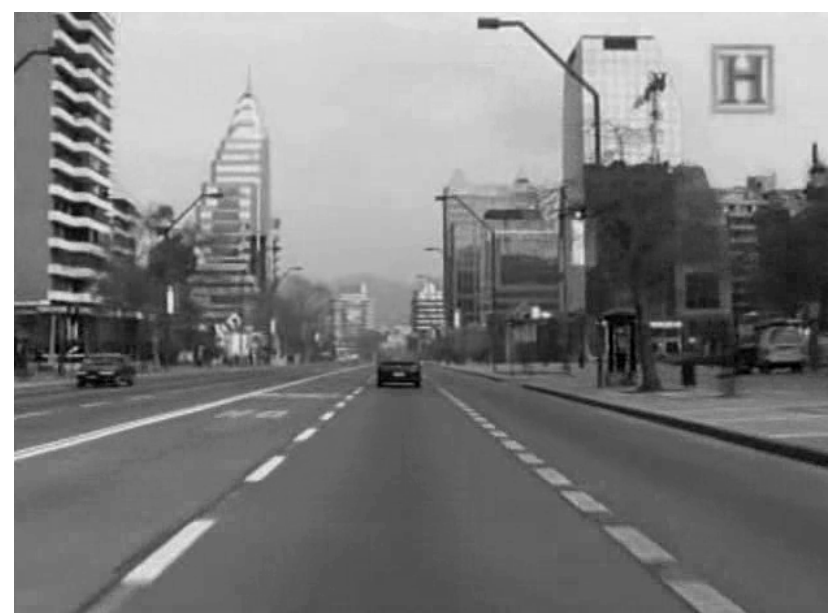

Figura 2: Fotograma de / love Pinochet

En la novela se convierte en personaje de ficción a una figura identificable del campo literario chileno: José Miguel Ibáñez Langlois, un sacerdote numerario del Opus Dei, poeta y crítico literario del periódico El Mercurio, que publicaba sus artículos con el seudónimo Ignacio Valente. Bolaño se enfrenta así al desafío de narrar la historia política chilena desde el punto de vista de un cómplice del régimen militar.

En Opus Dei..., Marcela Said y Jean de Certeu atraviesan ese mismo dilema, ya presente en I Love Pinochet, y recurren al testimonio de Ibañez Langlois, célebre por haber sido el encargado de dar clases sobre marxismo a los principales responsables de la dictadura y por participar de las veladas literarias organizadas por Mariana Callejas. ${ }^{14}$ En el documental, Ibañez Langlois se erige en vocero de las políticas educativas del Opus Dei y precisa las diferencias que imagina entre la idea de "censura" y las "medidas mínimas de prudencia en la formación intelectual de los fieles”, que lo llevan a especificar cuáles son las lecturas a las que tienen o no acceso los estudiantes de la Universidad de Los Andes.

Tanto en la novela de Bolaño como en el documental de Said y De Certeau, la elección de Ibañez Langlois

14:: La vida de Callejas (1932-2016) osciló entre la literatura y el crimen. Se desempeñó como agente de la DINA durante el régimen pinochetista. En su célebre casa de Lo Curro organizaba veladas literarias a las que asistía una parte considerable del campo cultural chileno, al mismo tiempo que servía como centro de detención y tortura. Pedro Lemebel recupera su historia en su crónica "Las orquídeas negras de Mariana Callejas" y Roberto Bolaño (2011) en su novela Nocturno de Chile, en la que la ficcionaliza bajo el nombre de María Canales. 
(ficcionalizado en un caso, incluido como testigo en el otro) supone abordar las alianzas entre el pinochetismo y el Opus Dei, entre la cultura y la barbarie, entre las pertenencias religiosas y las élites económicas. La aproximación a la historia chilena es más indirecta aquí que en I Love Pinochet, pero igualmente articuladora del documental. El Opus Dei formaliza las sombras del pasado de la dictadura que invaden el proceso de la transición democrática.

La pregunta de Said y De Certeau acerca de cómo narrar desde el punto de vista de los miembros del Opus Dei sin replicar su posicionamiento puede afrontarse a través de la recuperación de dos notables artículos de JeanLouis Comolli: "Mi enemigo preferido” y “Cómo filmar al enemigo?”. La coyuntura de la política francesa de los años noventa (marcada por el crecimiento del Frente Nacional de Jean-Marie Le Pen) lleva a Comolli a intentar desentrañar cómo puede filmar al enemigo el cine documental. Consciente de los riesgos derivados de este gesto, se pregunta qué manera de visibilizar este movimiento puede funcionar como herramienta política.

El cine debe asumir su capacidad para "atravesar las defensas del enemigo, exponer sus fuerzas y sus debilidades, desmontar sus recursos, hacer aparecer sus contradicciones" (Comolli, 2007, p. 273). Por eso, sugiere que debe evadir la tentación de forzar la puesta en escena. Si el enemigo necesita manejar las formas de su aparecer, la principal intervención del cine consiste en darle otro cuerpo y otra entidad a este actor político. Comolli confía en que la mirada y la escucha minuciosas conducen ineludiblemente a un desenmascaramiento. La premeditada neutralidad del registro debe lidiar, sin embargo, con un peligro doble: la hostilidad por un lado, la seducción por el otro. Esto se debe a que la captura no se limita a lo previsible de las conductas y las discursividades, sino también a lo imprevisible: un resto de humanidad.

El registro cinematográfico no puede eludir la intrusión de aquello que puede desmantelar su propia operatoria política, la percepción de aquello que iguala al realizador y al entrevistado. El intento de cuestionamiento puede conducir a la atracción por aquél a quien se intentaba develar. Por este motivo, la atención de Comolli se aboca a pensar los recursos que pueden sortear estos obstáculos y asegurar la eficacia política de su acción estética. Este dilema, presente en I Love Pinochet, adquiere en Opus Dei, una cruzada silenciosa una nueva formulación, dado que en este caso la capacidad de escamoteo ante la visión es mucho más radical que en el caso de los pinochetistas. A partir de allí, en el marco de un régimen de visibilidad articulado en torno a lo oculto, la pregunta de Said y De Certeau es cómo filmar al Opus Dei, su funcionamiento y sus compromisos, su pasado y sus sistemas de alianzas.

Si comenzar I Love Pinochet con la liberación del dictador suponía implementar una estrategia de reescritura de la historia desde un pasado activo en el presente, en este caso resulta igualmente significativo que el inicio remita al 6 de octubre de 2002, cuando el fundador del Opus Dei, Josemaría Escrivá de Balaguer, fue canonizado. De esta manera, se propicia un desmontaje del mito cuando este se encuentra ya legitimado. Aunque gran parte de la información que aporta el documental confirma y amplía los saberes circulantes, esta se incluye en una reflexión acerca de sus lazos con la articulación de lo visible y lo invisible.

Si en I Love Pinochet el desafío consistía en desarmar los modos de aparecer construidos por los pinochetistas, aquí la tarea se orienta a hacer visible una organización caracterizada por su voluntad de evadir la visibilidad. Dado que la búsqueda emprendida por sus autoridades se orienta a permanecer en el silencio y la oscuridad, el intento por hacerlo audible y visible constituye un gesto de desmontaje radical. Said y De Certeau buscan y configuran dispositivos que les permitan hacer visible y audible no lo invisible y lo mudo, sino lo oculto y lo silenciado. A partir de la recurrencia de referencias a lo que se esconde, adquiere mayor relevancia el testimonio 
de Alberto Moncada, un sociólogo y exnumerario posicionado como vocero del documental. Moncada explica la alianza entre el Opus Dei y las dictaduras (tanto el franquismo como el pinochetismo) como la causa de la conversión del secreto en la clave de su accionar.

Las dictaduras supondrían el lugar ideal para una organización que depende de la suma del poder político y económico para expandirse. Frente a esta voluntad de opacidad, en el documental de Said y De Certeau se formaliza un sistema de aperturas y cierres evidenciado en la recurrencia de puertas y ventanas, cortinas y portones, en los momentos de abrirse y cerrarse. Esta recurrencia convierte a estos objetos y situaciones en el leitmotiv que figura el funcionamiento selectivo de estas entradas, clausuras y expulsiones.

Este sistema de aperturas y cierres remite a las prácticas con lo (in)visible operadas por el Opus Dei. Frente a estas, en el documental de Said y De Certeau se implementan diferentes abordajes que explicitan la voluntad de visibilizar aquello que se intenta ocultar. Si bien se entrevista a algunos de sus integrantes más prominentes (ejecutivos de empresas, presidentes de cámaras empresarias, autoridades de la Universidad de Los Andes ${ }^{15}$ ) y también a otros menos relevantes, en todos los casos los entrevistados regulan aquello que dicen y muestran acerca del Opus Dei. Sin embargo, aunque las preguntas son dóciles ante el discurso esgrimido, este es posteriormente intervenido y desmentido por la autoridad de la voice over.

A su vez, la visibilidad articulada desde el Opus Dei es interrogada al inmiscuirse en algunas de sus instituciones: las escuelas en las que las alumnas explican cuál es la "educación espiritual" que reciben; las "milicias de Cristo" que propagan sus convicciones en los sectores socialmente más vulnerables; la misa de un cura que apela al cuarto mandamiento para reforzar el respeto a los carabineros; el IESE (el Instituto de Estudios Superiores de la Empresa) de Madrid, que les confirma a los economistas neoliberales la importancia del mercado

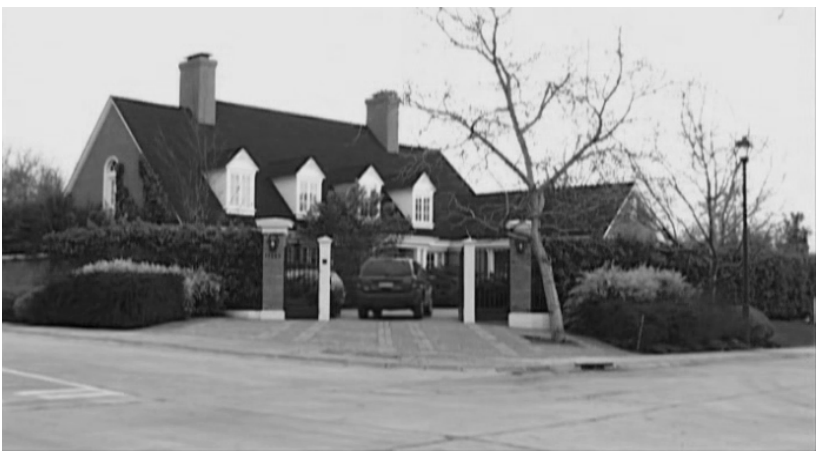

Figura 3: Fotograma de Opus Dei, una cruzada silenciosa

como regulador social; el centro de formación Fontanar para empleadas domésticas, que les enseña el valor de la obediencia; el colegio Nocedal ubicado en La Pintana, uno de los barrios más pobres de Santiago. Esta institución adquiere una relevancia particular porque se la define como la "vitrina" del trabajo social del Opus Dei en Chile y evidencia la voluntad de regular lo visible y seleccionar cuáles de sus establecimientos son sometidos al escrutinio público.

En su búsqueda por desmontar el régimen de aperturas y cierres implementado por el Opus Dei, en el documental se le atribuye un rol clave a la mostración de las fachadas de sus edificios y de las propiedades de sus miembros. Los frentes constituyen un comentario acerca de la clase social a la que pertenecen y defienden sus integrantes y acerca de sus modos de (des)aparecer (Figura 3).

Los ejercicios de visibilidad no podrían estudiarse fuera de su conflicto con lo invisible. Por un lado, el documental apela a visibilizar algo que se considera, en el marco del Opus Dei, que debe ser recluido en la invisibilidad: los cuerpos del personal doméstico. En la residencia universitaria Alborada se explica a los moradores que no deben ver a los miembros del servicio doméstico. Y a estos se les inculca que deben cumplir sus tareas sin ser percibidos. Frente a esta imposición, el documental se dedica a registrar las clases que reciben las futuras empleadas en el centro de formación; sus propios testimonios en

15:: En el documental adquiere particular importancia la figura del político y economista neoliberal Joaquín Lavín. En 1987 publicó su libro Chile, la revolución silenciosa, una defensa del modelo neoliberal implementado por el pinochetismo, cuyo título dialoga con el subtítulo del documental de Said y De Certeau. 
las cocinas de las casas de la alta burguesía en las que trabajan; sus trabajos a escondidas en las residencias universitarias y en el resto de las instituciones registradas en el documental. De esta manera, el documental restituye la presencia y los trabajos invisibilizados por el régimen de ocultamientos del Opus Dei (Figura 4).

Por otro lado, en ciertas ocasiones la invisibilidad implica ofrecer seguridad a ciertos actores sociales que brindan su testimonio. Así, lo invisible aparece en la voluntad de escamotear los rostros de ciertos testigos; en particular, de aquellos que fueron integrantes del Opus Dei. La opción por la invisibilidad supone un acto de protección. Si en el documental de Said y De Certeau la visibilización se concibe como una posible estrategia de fragilización, la sustracción del campo de lo visible se piensa como una posible forma de resguardo. El rostro en fuera de campo, la captura de espaldas, la noche como escenario de la interlocución, son recursos que se ponen en juego para evadir la mostración y la consecuente fragilización de los testigos. Este escamoteo no hace más que subrayar, mediante su trabajo sobre la ausencia, el terror a las prácticas persecutorias. De esta manera, el documental interviene y subvierte la distribución de lo visible al asegurar no solo la capacidad de mostrar para someter a escrutinio, para extraer del dominio cerrado y exponer a la vista pública, sino también para imponer en el territorio de lo común lo que queda oculto en una organización que se configura en torno a una mecánica de la veladura y el silencio. Estas intervenciones funcionan como un método de lectura que hace legible lo oculto y audible lo secreto.

\section{El mocito: visibilidades no restitutivas}

En El mocito, Said y De Certeau retoman algunas de las exploraciones ya realizadas, pero a través de una serie de torsiones que radicalizan las búsquedas previas. El documental comienza y concluye con sendos carteles informativos. El primero refiere a las violaciones de los derechos humanos perpetradas en Chile durante la dic-

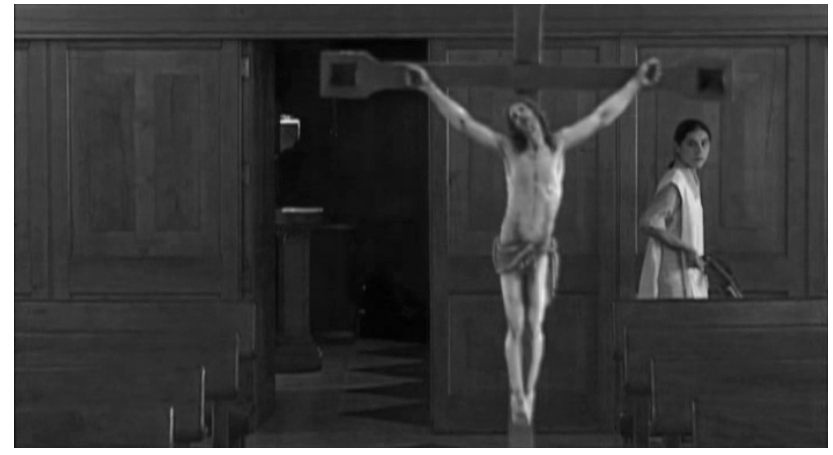

Figura 4: Fotograma de Opus Dei, una cruzada silenciosa

tadura y señala que "más de tres mil funcionarios civiles y militares participaron de estos crímenes. A la fecha, la justicia chilena ha condenado a 260 agentes, de los cuales 51 cumplen pena efectiva”. A partir de allí, El mocito se centra en la vida y el testimonio de Jorgelino Vergara, quien fue empleado en su adolescencia por Manuel Contreras, el jefe de la DINA, para realizar tareas domésticas en una de sus propiedades. Poco tiempo después Contreras lo llevó a trabajar a la brigada Lautaro en el cuartel Simón Bolívar, un centro de detención y exterminio. Allí, se dedicaba a alimentar a los prisioneros, limpiar las salas de tortura y atender a los militares. El último cartel del documental informa que en 2007 su testimonio le "permitió al juez Montiglio procesar a 74 agentes de la DINA convirtiéndose en el caso de derechos humanos de mayor envergadura”.

La figura pública de Vergara no solo es relevante por los efectos políticos y jurídicos que pone en juego, sino porque abre un interrogante acerca de la responsabilidad individual -se considera a sí mismo un "partícipe involuntario" y en una entrevista con el abogado especialista en derechos humanos Nelson Caucoto reclama una indemnización como víctima del terrorismo de Estado-y la sanción de la sociedad civil. Al mismo tiempo, a través de su testimonio se indagan los territorios imprecisos y las zonas grises de la historia.

La elección de Vergara como sujeto histórico mediante el cual afrontar la criminalidad de la dictadura y la conflictividad del período transicional supone la irrupción de una mayor complejidad que la presente en los documentales anteriores. Aquí no se trata de visibilizar a los responsables directos del terrorismo de Estado, sino de abordar a un personaje irrelevante en el pasado político chileno, pero devenido testigo y actor (menor) de la historia. El diminutivo del título, en este sentido, remite tanto a la edad que tenía cuando comenzó a trabajar para Contreras como al carácter de minoridad que se le atribuye por su rol subordinado. 
Si Vergara opera como pars pro toto de la dictadura, lo hace de una manera desviada: aunque constituye el eslabón más periférico de la jerarquía, puede aportar un testimonio clave sobre su funcionamiento. Said y De Certeau erigen a este personaje en la "figura-eco" (Stoichita, 2018) mediante la cual se accede al documental. Esta posición promueve una perturbación de la mirada y la escucha de los espectadores, un malestar derivado de los gestos oscilantes de proximidad y distancia, una interrogación de los efectos que genera Vergara en su entorno y en los espectadores (Parra Z, 2012).

En un análisis de El mocito, Ana Laura Ros (2018) se pregunta si puede haber víctimas entre los victimarios e inocentes entre los culpables. En su interpretación, el documental sugiere que, entre los polos incuestionables de las víctimas y los victimarios, hay un amplio espectro de varios grados, sombras, e incluso sobreposiciones (p. 114). En este sentido, coincide con la propuesta de Fernando Canet (2020) de pensar a los perpetradores en un continuum y no en una categoría única. Esto permitiría evadir el riesgo de analizar a los actores desprendidos de las circunstancias y de los diversos grados de implicancias en las prácticas represivas y criminales (p. 168).

Por el contrario, Michael Lazzara (2014) concibe al documental como un retrato generoso del cómplice que lo pone en escena como un sujeto reformado ( $p$. 95). En tanto Lazzara sugiere que el documental diluye las responsabilidades de Vergara al hacer hincapié en el escenario social del que emerge, podría pensarse, en coincidencia con lo señalado por Ros, que las circunstancias no desvanecen las responsabilidades, pero sí convocan a la necesidad de incluir no solo el entorno social, económico y cultural de Vergara, sino también las deudas derivadas de la conservación de esa estructura social en la democracia.

A diferencia de los documentales asertivos previos, aquí se configura un acercamiento construido en torno a lo ambiguo. Vergara se concibe a sí mismo como una víctima; sin embargo, algunos vecinos testimonian que presumía del poder que detentaba, o decía detentar, den- tro de las fuerzas represivas. Así, en tanto él se define como un sujeto utilizado por el poder, se lo presenta también como testigo y cómplice de este. De allí deriva la dificultad de abordar sus posiciones morales, ideológicas y hasta jurídicas.

En El mocito se imposibilita el establecimiento de la veracidad de aquello que Vergara afirma sobre su compromiso con las prácticas criminales de la brigada Lautaro. La ambigüedad, que aparece por primera vez en los documentales dirigidos por Said, se inscribe aquí a través de dos procedimientos claves: uno es la ausencia de voice over, recurso articulador de la argumentación en I Love Pinochet y Opus Dei, una cruzada silenciosa. La formulación contundente de hipótesis se sustituye por una observación detallista de Vergara y su cotidianeidad.

El otro procedimiento reside en la multiplicación de los puntos de vista. Estos no se encadenan en una serie ordenada por refutación o confirmación y se asume el carácter indemostrable del pasado del personaje. Lejos de acentuar la credibilidad de una única perspectiva, en El mocito se explora la diseminación de estas voces. Los vecinos afirman que Vergara decía ser capitán del ejército; su hermano argumenta que fueron las circunstancias (la juventud, la pobreza, el trabajo para el General Contreras, la soledad en Santiago) las que lo llevaron a cumplir ese rol; Morales, su antiguo jefe, desmiente su presunta inocencia.

En El mocito se presenta a Vergara como un autoexpulsado de la civilización. En 2007, cuando fue convocado para declarar en la investigación por el homicidio del dirigente del Partido Comunista Víctor Díaz López, vivía en la clandestinidad en Curicó, en el sur de Chile. En el documental se registran las afueras desoladas donde habita y las formas en las que se provee su propio alimento a través de la caza. Se trata de un sujeto que parece ser invisible para el espacio urbano cuando ocasionalmente lo visita (la iglesia evangelista, los restaurantes precarios). El contraste con los dirigentes del aparato represivo es contundente: estos gozan de las ventajas económicas de las que carece 


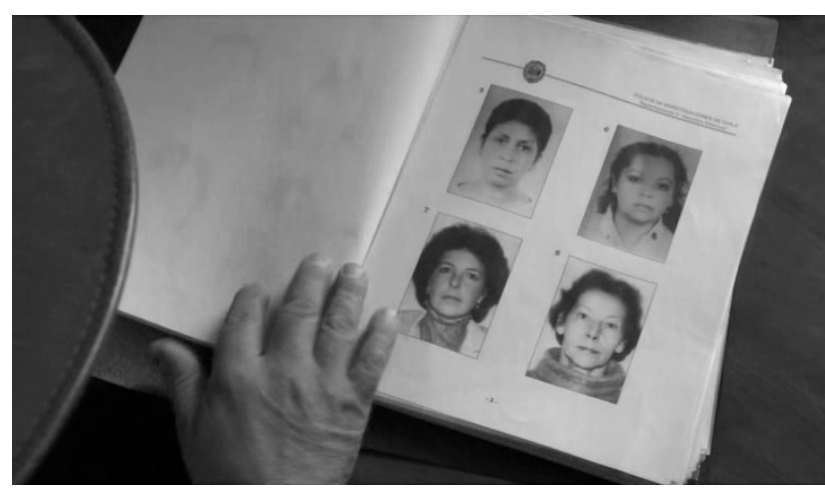

Figura 5: Fotograma de El mocito

Vergara; este disfruta de los beneficios derivados de no haber sido la autoridad responsable de las violaciones a los derechos humanos. ${ }^{16}$ La conversación con Juan Morales Salgado, organizada como un careo informal, resulta esclarecedora al respecto. En el tono amable de la reunión, encuadrada por las declaraciones de respeto mutuo, se dirime no tanto la veracidad de lo enunciado por Vergara como la conformación de una batalla de relatos acerca del pasado.

En esta dirección, la anterior construcción de un cine-funa reaparece en $\mathrm{El}$ mocito de una manera desviada. Esta se presenta a través de la aparición de material de archivo de la funa realizada frente a la propiedad de Germán Barriga, integrante de la DINA y la Central Nacional de Informaciones (CNI), y jefe del Grupo Delfín operante en el cuartel Simón Bolívar. Este registro, en consonancia con el proyecto de un cine-funa de I Love Pinochet y Opus Dei..., ocupa aquí una posición periférica. Ya no se trata de articular al documental como recurso para funar a los miembros más impunes de la dictadura y sus aliados civiles, sino de problematizar la responsabilidad de los eslabones menores de la cadena de exterminio, articular desde allí un develamiento de los estragos producidos por el régimen pinochetista y explorar la capacidad del documental para gestar los recursos necesarios para profundizar en el terreno de lo ambiguo e indeterminado.

En esta búsqueda, más inquisitiva y menos asertiva, las fotografías ocupan un lugar preponderante. A diferencia de otros documentales, en los que se apela a la imagen de las víctimas para recuperar sus memorias, ${ }^{17}$ aquí se privilegian las fotografías de los perpetradores. Vergara observa un archivo fotográfico de los responsables de la brigada Lautaro y otros genocidas e identifica y nombra a

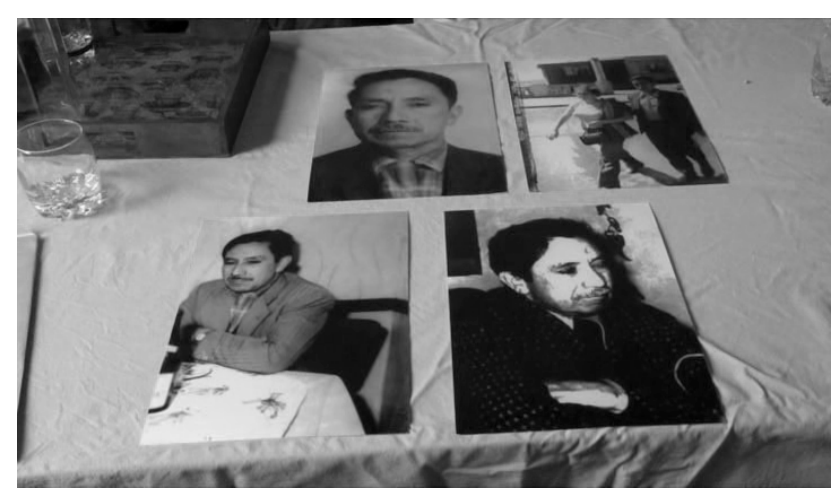

Figura 6: Fotograma de El mocito

los agentes de la DINA reseñados allí. Los retratos ya no se ponen al servicio de una función honorífica, sino de una incriminatoria (Figura 5).

Estas fotos, que cumplen con el formato requerido por los prontuarios policiales, configuran un archivo de justicia dedicado a establecer la memoria de los crímenes. La imagen fotográfica también articula el desenlace del documental. Allí, Vergara se reúne con los hijos de Daniel Palma, un militante del Partido Comunista asesinado en el cuartel Simón Bolívar, y se convierte en el primer testigo que certifica su detención clandestina y su muerte. Ante las fotografías de Palma, mostradas por los hijos, y el pedido de estos de identificar a los responsables de su asesinato, Vergara elabora la lista correspondiente. Esa enumeración, que fue luego testificada ante el juez, compone otro eslabón de este archivo móvil e incompleto del terrorismo de Estado (Figura 6).

16:: Puede establecerse un lazo entre este documental y la segunda ficción dirigida por Said: Los perros (2017). Este proyecto surgió durante la investigación previa al rodaje de El mocito, cuando Said conoció al exjefe de Vergara, Juan Morales Salgado. La cineasta decidió tomar clases de equitación con él para que la conociera y accediera a brindar su testimonio para el documental. Esta situación constituye la base argumental de Los perros, en la que Said retorna los enlaces de las clases dirigentes civiles chilenas y la dictadura. Un abordaje cercano, centrado en el funcionamiento del grupo paramilitar Patria y Libertad, puede encontrarse en Araña (Andrés Wood, 2019).

17:: En Chile, la memoria obstinada (1997), Patricio Guzmán configura un archivo de las ausencias a través de la revisión de viejas fotografías de activistas políticos desaparecidos durante la dictadura. Los sobrevivientes, defensores del Palacio presidencial durante el golpe de Estado, contemplan las fotografias y reconstruyen, a partir de alli, la identidad y el destino de los fotografiados. 
Said y De Certeau interrogan, en El mocito, la posibilidad de buscar estrategias no restitutivas para figurar la historia reciente de Chile. Sus huellas aparecen en la oralidad del testimonio de Vergara, en sus descripciones y en sus referencias a los padecimientos de las víctimas. La potencia del relato oral se tensiona, sin embargo, con la ausencia de restitución visual del pasado. Conviene recuperar aquí el acercamiento propuesto por Eduardo Grüner a la noción de "invisibilidad estratégica". En un siglo marcado por la desaparición colectiva, precisa, "el arte abandona el referente del cuerpo humano singular y concreto para hablar -indirectamente- del vacio de figuración posible de ese cuerpo en un mundo cuya propia gestalt está irremediablemente fracturada por la fantasmática de unos cuerpos violentamente "ausentados" (Grüner, 2008, p. 289).

El arte indaga las formas de evitar el congelamiento de la memoria en la fotografía de prontuario extraída por los perpetradores. En esta dirección, Grüner no formula un absoluto de la ausencia ni de la presencia, sino que piensa cuáles fueron las estrategias articuladas por los artistas para figurar esos cuerpos ausentados. ${ }^{18}$ En esa búsqueda, desprecia la recurrencia de las políticas de restitución sustitutiva que intentan compensar el vacío. Por el contrario, le interesa revisar aquellas prácticas estéticas que fomentaron la emergencia de lo ausente a través del señalamiento de la falta. El vacío es rodeado por la construcción de un discurso que dice lo ausente, sin apelar a ningún modo de mostración. De esta manera, esta "invisibilidad estratégica" puede operar una remoción de las modalidades restitutivas del arte y hacer evidente la imposibilidad de la sustitución.

Los planos del cuartel Simón Bolívar vacío introducidos en El mocito funcionan en esta dirección. Vergara recorre los espacios del antiguo centro, explica su distribución espacial y narra ciertos episodios allí ocurridos. En otros planos, el espacio no habitado, con carteles que especifican el uso que tenía cada uno de los ambientes, testimonia elocuentemente la criminalidad del terrorismo de Estado. La tensión entre la imagen que muestra la falta y la palabra que bordea lo innombrable se vuelve así articuladora del documental: lo decible y lo inmostrable, lo actual y lo pasado, lo presente y lo ausente. En estos territorios de la incerteza se asienta la perturbación de un orden que piensa la imagen y el discurso como afurmaciones y se impone una concepción del documental como interrogación. Desde este posicionamiento inquisitivo, se revisa la historia chilena para narrar las ausencias mediante los testimonios de los eslabones más precarios que participaron de esa desaparición.

\section{Conclusiones}

Marie-José Mondzain (2016) defiende que la única imagen que tiene la posibilidad de transformar la violencia en libertad crítica es la imagen que encarna, aquella que da materialidad y visibilidad a una ausencia. Este vacío, sin embargo, puede ser conjurado no solo a través de los intentos (siempre fallidos) de restitución, sino también a partir de la apelación a las condiciones y los responsables de esa desaparición. En esta búsqueda, en I Love Pinochet, Opus Dei, una cruzada silenciosa y El mocito se indagan los conflictos derivados del acceso, o no, a la visibilidad.

En I Love Pinochet, Said escruta las imágenes y los discursos articulados por los pinochetistas para desmontar su funcionamiento. Introduce sus relatos y memorias para desarmar los modos en los que estos sectores regulan su propio aparecer público. Así, genera una torsión de sus memorias y las abre al debate desde el presente. En Opus Dei..., Said y De Certeau se encargan de rediseñar la distribución de lo visible propiciada por esta orden religiosa. Proponen, así, una intervención que encarna lo oculto y explicita lo silenciado. Finalmente, en El mocito, elaboran estrategias que piensan la potencia de tensar la relación imagen-palabra y encuentran procedimientos orientados a examinar de qué manera lo invisible puede aportar una reflexión sobre lo ausente que desmantele tanto el vacío fomentado desde el poder como las producciones simbólicas articuladas en torno a la sustitución.

\footnotetext{
18:: Resulta inevitable, en el marco de las prácticas audiovisuales, recuperar las célebres disputas en torno a Shoah (Claude Lanzmann, 1985). Las participaciones de Georges Didi-Huberman, Gérard Wajcman, Jean-Luc Godard, Jacques Rancière y el propio Lanzmann constituyen la base de uno de los debates más relevantes de la estética contemporánea.
} 
En los tres casos, puede recuperarse la noción de "invu" sugerida por Mondzain para pensar "aquello que está a la espera de sentido en el debate de la comunidad. Tal situación de decidibilidad del sentido supone que la imagen, por sí misma, es fundamentalmente indecisa o indecidible" (Mondzain, 2016, p. 37). Precisamente porque la imagen es en sí misma ambigua, equívoca e incompleta, Said y De Certeau configuran dispositivos en los que las memorias de los perpetradores y sus cómplices, los relatos con los que asignan inteligibilidad a la historia reciente chilena y las imágenes con las que cristalizan un relato del pasado, son intervenidos y sometidos a una lectura crítica. En estos procesos de desmontaje, a su vez, se abren las hendiduras por las que se inmiscuyen las memorias de las víctimas, los reclamos de justicia y las funas a los genocidas.

\section{Referencias}

Barraza, V. (2018). El cine en Chile (2005-2015). Políticas y poéticas del nuevo siglo. Santiago, Chile: Cuarto propio.

Bolaño, R. (2011). Nocturno de Chile. Barcelona, España: Anagrama.

Canet, F. (2020). Introductory Reflections on Perpetrators of Crimes Against Humanity and their Representation in Documentary Film. Continuum, 34(2), 159-179. Recuperado de https://www.tandfonline. com/doi/full/10.1080/10304312.2020.1737429

Comolli, J. (2007). Very poder. Cine, televisión, ficción, documental. Buenos Aires, Argentina: Aurelia Rivera.

De los Ríos, V., y Donoso, C. (2016). Apuntes sobre el documental chileno contemporáneo. Nuestra América, 10, 207-219. Recuperado de https://bdigital.ufp.pt/bitstream/10284/6767/1/Nuestra\%20 america_nr10_14.pdf

Donoso Pinto, C. (2012). Sobre algunas estrategias fílmicas para una propuesta de primera persona documental. Comunicación y medios, 26, 23-30. Recuperado de https://comunicacionymedios.uchile.cl/ index.php/RCM/article/view/24791

Gahona, Y. (2003). Si no hay justicia... hay funa. Revista Virtual ILAS, 3. Recuperado de https://www.archivochile.com/Derechos_humanos/ FUNA/hhddfuna0000a.pdf

Glissant, É. (2006). Tratado del Todo-Mundo. Barcelona, España: El cobre. Grüner, E. (2008). La invisibilidad estratégica, o la redención política de los vivos. En A. Longoni y G. Bruzzone, El siluetazo (pp. 285-308). Buenos Aires, Argentina: Adriana Hidalgo.
Jay, M. (2007). Ojos abatidos. La denigración de la visión en el pensamiento francés del siglo XX. Madrid, España: Akal.

Lazzara, M. (2014). El fenómeno Mocito (Las puestas en escena de un sujeto cómplice). A contra corriente, 12, 89-106. Recuperado de https://acontracorriente.chass.ncsu.edu/index.php/acontracorriente/ article/view/1301

Marín, P. (2019). Chile del 2000 y después: el cine de una transición incierta. En M. Veliz, Cines latinoamericanos y transición democrática (pp. 147-162). Buenos Aires, Argentina: Prometeo.

Mondzain, M. (2016). ¿Pueden matar las imágenes? Buenos Aires, Argentina: Capital intelectual.

Mouesca, J. (2005). El documental chileno. Santiago, Chile: Lom Ediciones. Moulian, T. (1997). Chile actual. Anatomía de un mito. Santiago, Chile: Arcis.

Parra Z., J. (2012). El Mocito. La Fuga, 13. Recuperado de http://www. lafuga.cl/el-mocito/492

Pinto, I. (2016). Formas expandidas. Límite y entre-lugares del documental chileno 2004-2016. Revista Cine Documental, 14, 101-144. Recuperado de https://revista.cinedocumental.com.ar/tag/ivan-pinto-veas/

Richard, N. (2010). Crítica de la memoria (1990-2010). Santiago, Chile: Universidad Diego Portales.

Richard, N. (2015). Latencias y sobresaltos de la memoria inconclusa (Chile: 1990-2015). Villa María, Argentina: EDUVIM.

Ros, A. (2018). El mocito: A Study of Cruelty at the Intersection of Chile's Military and Civil Society. Genocide Studies and Prevention: an International Journal, 2, 107-124. Recuperado de https://scholarcommons. usf.edu/gsp/vol12/iss2/8/

Stoichita, V. (2018). El efecto Sherlock Holmes. Variaciones de la mirada de Manet a Hitchcock. Madrid, España: Cátedra.

Thayer, W. (2006). El fragmento repetido. Escritos en estado de excepción. Santiago, Chile: Metales pesados.

Valderrama, M. (2018). Prefacio a la postdictadura. Santiago, Chile: Palinodia.

Vergara, C., y Bossy, M. (2010). Documentales autobiográficos chilenos. Santiago, Chile: Fondo de Fomento Audiovisual del Consejo Nacional de la Cultura y las Artes.

Villalobos-Ruminott, S. (2016). Las edades del cadáver: dictadura, guerra, desaparición (postulados para una geología general). En Heterografías de la violencia. Historia Nihilismo Destrucción (pp. 199-214). Buenos Aires, Argentina: La Cebra.

Contribución autoral: a) Concepción y diseño del trabajo; b) Adquisición de datos; c) Análisis e interpretación de datos; d) Redacción del manuscrito; e) revisión crítica del manuscrito. M. V. ha contribuido en a, b, c, d, e. 